\title{
TOPRAKTAKİ BİTKİ BESİN MADDESİ HAVUZU KAPSAMINA GİREN BAZI TERIMMLERINN KULLANILIŞLARI
}

\author{
Hüseyin Barış Tecimen ${ }^{1}$ \\ 1)İstanbul Üniversitesi-Cerrahpaşa, Orman Fakültesi Toprak İlmi ve Ekoloji Anabilim Dalı, Bahçeköy-İstanbul, \\ İleti: hbarist@gmail.com, ORCID ID: 0000-0001-7072-3026
}

\section{Özet}

Bitki besin maddesi döngüsü ve topraktaki havuzları, orman sağllğı ve beslenmesini doğrudan etkileyen en önemli bileşenlerden biridir. Toprak içinde gerçekleşen muhtelif süreçlerin sonunda alınabilir hâle geçen topraktaki besin maddeleri, toprak içinde çeşitli havuzlarda kısa veya uzun sürelerle durmakta ve buradan da belirli süreçleri geçirdikten sonra bitkiler veya mikroorganizmalar tarafindan alınmaktadır. Topraktaki besin maddesi havuzlarının neler olduğu hakkında genel bir fikre sahip olunmakla birlikte, bu çalısma kapsamında ele alınan havuz terimlerinin, tam olarak neyi ifade ettiği, Türkçe ve yabancı yayınlarda bilinen kapsamlı tanım ve kullanımlarının nasıl yapıldığı, bir besin maddesi havuzunun hangi farklı kavramlarla ifade edildiği ve aralarında anlam boşlukları ve farklılıklarının neler olduğu incelenmiștir. Yapılan değerlendirme sonucunda, (i) 1980'lerde önceden beri kullanılan terimlerin daha doğru ve karışıklı içermeyen şekilde kullanıldığı; (ii) üzerinde çalışma yapılan konuların yoğunluğu arttıkça, terimlerin sıklıkla kullanılan hâllerinde bir devamlılı̆̆n yakalandığı (toprak organik maddesi, ölü örtü gibi) ve (iii) son zamanlarda yapılan çalş̧malardaki konuların ve kavramların doğrudan İngilizce üzerinden yapılmasından dolayı (microbial biomass, plant biomass gibi), Türkçede belirli bir karşıllğ̆ının henüz yerleşmediği tespit edilmiştir.

Anahtar kelimeler; Besin Maddesi Havuzu, Ölü Örtü, Organik Madde, Toprak Çözeltisi.

\section{USAGE OF SOME SOIL NUTRIENT ELEMENT TERMS}

\section{Abstract}

Plant nutrient cycle and pools in the soil are one of the most important components that directly affect forest health and nutrition. The nutrients in the soil, which have become available at the end of various processes occurring in the soil, exist in various pools in the soil for a short or long time and subsequently, they are taken by plants or microorganisms. Although we have a general idea about what nutrient pools are in the soil, the exact definitions of pool terms, the comprehensive definitions and uses known in Turkish and foreign publications, the conceptual differences and gaps between the nutrient pool terms are examined. As a result of the evaluation, (i) the terms used before 1980s were used more accurately and without confusion; (ii) as the intensity of the subjects studied has increased, a continuity is caught in the frequently used terms of the terms (such as soil organic matter, forest litter) and (iii) due to the fact that the topics and concepts in recent studies have been conducted directly in English (such as microbial biomass, plant biomass) the attempts to seek any essential definitions in Turkish have been omitted.

Keywords; Nutrient Element Pool, Forest Litter, Organic Matter, Soil Solution. 


\section{Giriş}

Topraktaki bitki besin maddeleri, bitkiler tarafindan alınabilir hâle gelmesi, anakayanın parçalanması ve ayrışması, toprak oluşumu, besin maddelerinin dış havuzlarından toprağa geçişi ve mikroorganizma ve organik ve inorganik kimyasal ayrışma/indirgenme/yükseltgenme gibi süreçlerin sonunda meydana gelmektedir (Irmak, 1972; Brady, 2008). Bu olaylar üzerinde etkili olan iklim, toprak (toprak türü, $\mathrm{pH}$ vb), anakaya (Anderson, 1988), yeryüzü şekli, zaman, mikroorganizmalar (Shulz ve ark., 2013) ve bitki örtüsü faktörlerinin etki yönleri doğrultusunda, topraktaki besin maddelerinin belirli bir zamandaki miktarı, toplam miktarı, alınabilir ve değiştirilebilir olanlarının miktarı değişim gösterektedir. Bitkiler tarafından besin maddelerinin alınması ve toprağa tekrar çeşitli kanallardan geri dönmesi besin maddesi döngüsünün bitkiler tarafindan gerçek-leşebilmektedir (Sharma ve Sharma, 2004). Bitkilerin dışında, atmosfer ile yağışlarla gelen, yüzey sularıyla gelen ve diğer canlı faaliyetleriyle eklenen veya alınan besin maddelerinin varlığ1 söz konusudur. Bu çalışmada; bir ekosistemde; besin maddelerinin durağan veya değiştirilebilir olarak tutulduğu havuzları ifade eden terimlerin açıklamalarına yer verilmiştir. Böylece, toprakta besin maddesi döngüsü çalışmalarında kullanılmakta olan terimlerin hem Türkçe ifadelerinin doğru bir şekilde belirtilmesi ve hem de bu terimler ile ifade edilen süreçlerin hangi bileşenlerden oluştuğu ve neleri ifade ettiği konusunda bir başvuru kaynağ1 çalışması yapılması hedeflenmiştir. Her ne kadar bütün karasal ve sulak ekosistemlerde besin maddesi döngüsünden bahsetmek mümkün olsa da, bu çalışmada, orman ekosistemini esas alan besin maddesi döngüsü terimlerine ağırlıklı olarak yer verilmiştir.

Orman ekosistemlerinde, tarım ekosistemlerinde olduğu gibi dışarıdan ilâve olarak besin maddesi, gübre, $\mathrm{pH}$ düzenleyici vb. maddeler eklenmediği için, besin maddesi ekosistem içinde döngüsel olarak aktarılmaktadır. Her bir elementin kendine özgü havuz, havuzdan sisteme alınabilir forma dönüşüm, sisteme alınış ve sistem içinde izlediği yollar vardır (Bormann ve Likens, 1967). Bu itibarla, bu çalş̧mada, element düzeyinde ve elemente özgü döngü düzenini ifade eden terimleri değil, genel olarak bu çalışmalarda elementin nicel varlığının göstergesi veya besin maddesi seviyesi bilgisinin temin edildiği havuz, havuzdan ortama, ortamdan canliya akışs sırasında rastlanan dönüştürülme aşamaları ve canlı bünyesinde depolandığı organik havuzları ifade eden terimlere yer verilmiştir.

Orman ekosistemlerinde, karasal ekosistemlerin çoğunda olduğu gibi, besin maddesi havuzlarını atmosfer ve toprak oluşturmaktadır. Bununla birlikte, son yıllarda yapılan besin maddesi döngülerine ilişkin çalışmalarda, ekosistemlerdeki işlevlerin verimli bir şekilde yerine getirilip getirilmediği izlenmekte ve böylece, havuz sistemlerindeki element içerik yoğun-luklarının normal sınırlarda olup olmadığı ve bunların nedenleri de araştırılmaktadır (O'Neill ve ark., 1977; Svoboda ve ark., 2006; Laclau ve ark., 2010; Jandl ve ark., 2014; van der Heijden ve ark., 2017). Bu çalşsmalar dünyada ve ülkemizde çok uzun zamandır yapıla-gelmekte ancak, yabancı dilde kullanılmakta olan terimlerin Türkçede de bazen tam karşıllığının Türkçe olarak ifade edildiği, bazen yabancı dildeki terim kalıbının bir kısmı orijinal haliyle korunurken, bir kısmı için Türkçe karşılığ kullanıldığı, bazen de yabancı dildeki kelime köklerinin çevrilmesi zor olduğu için yine yabancı dildeki haliyle alınıp ve kullanıldığ1 ya da köklerin karşllığ olabilecek Türkçe kelimelerin; yabanc1 dildeki köklerin bir araya getirilmesine benzer şekilde yan yana getirilerek kullanıldığ1 görülebilmektedir. Nitekim, bu konularda yapilan önceki çalışmalarda incelenen ve ortaya konan sonuçlara göre, ekoloji teriminin anlamı dışında, anlamını karşılamayacak alanlarda veya doğrudan yanlış anlamlarda kullanılışlarının olduğu tespit edilmiştir (Sevgi ve Tecimen, 2008). Bu çalışmada, orman ekosistemlerinde gerçekleşen besin maddesi döngülerinde kullanılan başlıca terimlerin ortaya konulmasi; İngilizcede kullanılan terimlerin Türkçe anlamları ve ekolojik olarak ne ifade ettikleri; besin maddelerinin bulunduğu havuzlar, havuzlardan akışlar ve canlı sisteminde yarattığı değişimler ana başlıkları altında incelenecektir.

\section{Özdek ve Yöntem}

\section{Özdek}

Bu çalışmada, çalışmaya konu edilen terimler, orman ekolojisinin inceleme konularından biri olan bitki beslenmesi ve ekosistemlerde madde döngüleri konularında yapılmış olan çalışmalarda en çok konu edilen terimlerden oluşmaktadır. Bu maksatla, orman ekolojisi ve toprak bilimi çalışmalarında son 10 yılda en çok kullanılan terimler bu çalışmanın konusunu oluşturmaktadır. Konu başlığı olarak yapilan çalışmaların orman ekosistemlerinde yapilmış olmasina ve besin maddesi döngüsü konusunu işlemiş olmasina dikkat edilmiştir.

\section{Yöntem}

Ortaya konulan terimlerin kullanıldığ 63 adet yayın incelenerek, terimin yaygın veya özel bir anlamda kullanılıp kullanılmadığı incelenmiş; ormancilık bilimleri terim sözlüğünde bu terimin karşılloğ1 olarak sunulan 
tanım ile çalıșmada kullanılan anlamı karșılaștırılmıș ve 510 arasında sayıda çalışmada terimin ekseriyetle kullanılan anlamının hangisi olduğu incelenmiş ve Türkçe olarak mevcut karşıllğının, yapılan çalışmalardaki anlamları ile uyumlu olup olmadığı kontrol edilmiştir. Buna göre, aradaki anlam boşluğunu kapatmaya yönelik olarak terimin Türkçe karşıllığına ilişkin öneride bulunulmuştur.

\section{Havuz ifadeleri için kullanılan terimler}

Bu başlik altında, besin maddelerinin birikmiş halde bulunduğu havuzları ifade etmek için kullanılan terimlere yer verilmiştir. Besin maddesi havuzu olarak da ifade edilmekle birlikte, besin maddelerinin depolandığ1 canlı bitki kısımları; bitki artığı kısımları, besin maddelerinin değiştirilebilir ve/veya değiştiri-lemez veya özel çözücüler sayesinde değiştirilebilir hale gelir seviyelerde tutulan toprağın kolloid organik ve inorganik oluşumlan ile mikroorganizma toplumlarının bünyesinde tutulan besin maddeleri havuzları, bu başlık altında incelenmiştir.

Bitkisel canlı kütle: İngilizce literatürde "plant biomass" olarak ifade edilen bu terim ile, genellikle; odun yapısı ağıllkklı olarak ifade edilmekle birlikte; esas olarak; bitkilerin toprak üstünde yer alan yaprak, dal, gövde odunu ile toprak altında yer alan odunsu kökleri ve ince kökleri de içine alacak șekilde tamamını ifade etmekte kullanılmaktadır. Canlı kütle terimine karşılık gelen "biomass" terimi İngilizcede ilk olarak 1913 yllinda alglerin toplam canlı kütlesinin ifadesinde kullanılmış (Rao, 1913), daha sonra ise sık-lıkla kullanımı 1970'li yıllarda artmıştır (Baskerville, 1972). Ülkemizde ise ilk olarak bu kavram Irmak (1970) tarafindan "mahsul miktar1" olarak, Orman Ekolojisi kitabında sayfa 263 bölüm 8'de "Yetişme Muhiti Özelliklerinin Mahsul Miktarına Etkisi" başlığı altında, çok açık, anlaşılır ve Türkçe terimlerle ele alınmıştır. Ayrıca yetişme ortamı özelliklerinin canlı kütle üzerine etkileri, Çepel (1988) tarafindan Toprak İlmi kitabında sayfa 225'teki bölüm 8.3'te "Toprak Verimliliğinin Arttırılması ile İlgili Bazı Bilimsel Esaslar ve Teknik Uygulamalar" başlığı altında, canlı kütle artımını "ürün verimi”" söyleyişi olarak açık ve anlaşılır bir biçimde ifade etmiştir. Türkçe çalışmalarda "bitkisel kütle" olarak da yer almıştır (Karaöz, 1988). Bazı çalışmalarda ise, çalışmanın kapsamına göre; "toprak üstü bitkisel kütle" olarak da ifade edilmiştir (Güner ve Özkan, 2019). İngilizce makalelerde kullanılan "plant biomass" terimi, bu terim kalıbina ilave olarak "plant biomass production (Demura ve Ye, 2010); plant biomass accumulation (Fransen ve ark., 1999); plant biomass allocation (McCarthy ve Enquist, 2007) ve plant biomass growth (Moscatelli ve ark., 2001)" olarak da kullanımlarının olduğu görülmektedir. Ülkemizde yapılan çalışmalarda, daha çok "bitkisel kütle" olarak ele alınan bu terim, konu olarak orman, tarım veya mera gibi ekosistemlerde tutulan karbon miktarlarının ele alındığ1 makalelerde geçmekte ve genellikle, yapılan hesaplamalar ile bir alanda mevcut bulunan bitkisel kütlenin karşıllık geldiği karbon miktarı ortaya konulmaya çalışılmıştır (Karaöz, 1988; Tolunay, 2012). Türkiye Bilimler Akademisi (TÜBA) Bilim Terimleri Sözlüğünde bitkisel canlı kütle ve canlı kütle terimleri yer almamakla birlikte; "biyolojik kütle" maddesi altında, ormancilık disiplininde biyolojik kütlenin tanımı içinde "canlı kütle" ve "biyokütle" ifadelerine yer verilmiş ve maddenin tanımı "orm. Ekosistemde belirli bir zamanda, birim alanda veya hacimde bulunan canlı materyal miktarı; eșanlam: canlı kütle, biyokütle" şeklinde yapılmıştır (A $\breve{g} 1,2020)$. Çepel (1996) biyomas terimini, "biyolojik kütle" ile eşanlamlı kabul etmiş ve bunlara ek olarak canlı biyomas/dikili ürün olarak da ifade ettiği sözlügünde, terimin tanımını "bir ekosistemde belli bir zamanda, canl organizmalarn veya belirli kessmlarmn yüzey veya hacim birimine göre ifade edilen kütleleridir. Bitkiler için bitkisel kütle, hayvanlar için havvansal kütle olarak ifade edilir." șeklinde kaydetmiştir. Buradan da anlaşılacağı üzere, bitkisel canlı kütle terimi için, aynı zamanda bitkisel kütle ifadesinin de kullanılabileceği görül-mektedir.

Mikrobiyal canlı kütle: İngilizce literatürde "microbial biomass" olarak geçen ve Türkçe metinlerde de son zamanlardaki makalelerde genellikle mikrobiyal canlı kütle veya mikrobiyal biyomas olarak kullanılan bu terim; toprakta bulunan toplam mikroorganizmalarin ağırlık cinsinden değerini ifade etmektedir. İngilizce bilimsel yayınlar arasında İngilizce olarak rastlanan ilk yayın Kriss ve arkadaşları tarafından yayınlanan "The microbial biomass on the sea floor in the hydrogensulphide region of the Black Sea" adlı makale olup 1950 yilında yayınlanmıştır. 1950'li yıllara kadar çok kullanılmayan bu terim, 1970'li yıllardan itibaren yoğun olarak kullanılmaya bașlanmıș ve terimin makale başlı̆̆ında ve içindeki alt başlıklarda geçtiği makale sayıları artmışır. Mikrobiyal canlı kütlenin toprakta belirlenmesi için önerilen ve 1980-2000 yılları arasında ve hatta günümüzde de en yaygın olarak kullanilan kloroform buharı (KFB) ile tayin yöntemi Vance ve ark. (1987) tarafindan önerilmiștir. Toprak biliminde önemli yeri olan mikro canlilar, Irmak (1972) tarafindan da dikkate alınmış ve Toprak İlmi kitabında 6.5 numaralı "Toprağın Organizmaları" başlı̆ı altında mikrobiyal canlılar için "mikroskobik organizmalar" ve 6.5.2 numaralı başlıktaki "İlkel hayvanların fonksiyonu" ifadede "ilkel hayvanlar" terimleri olarak yer almıştır. Çepel (1988) tarafindan kaleme alınan Toprak İlmi kitabında ise toprak mikroorganizmaları konusu, 7 numaralı "Toprağın Biyolojik Özellikleri” başlığı altında italik olarak "toprak mikroflorası" olarak ifade edildikten sonra, ilgili bahsin ilerleyen kısımlarında "topraklardaki mikroorganizmalar" şeklinde ifade edil- 
miștir. Terimin tamamen Türkçe olarak ifade edilmeye çalıșılması ile anlaşılması zor veya anlam karışıklığına neden olabilecek yeni, Türkçe ama kullanışsız olan terimler doğabileceği için, kısmen Türkçe olarak "mikrobiyal canlı kütle" șeklinde kullanılması yaygın olarak devam etmektedir. Bu haliyle, terimde, Türkçede olmayan "mikrobiyal" sözcüğü bu terimin en önemli ve anlamı en fazla etkileyen sözcügü olup, bu sözcük üzerinde durulması gerekmektedir. TÜBA Bilim Terimleri Sözlüğünde de bu sözcüğün geçtiği "mikrobiyal biyokütle ölçümü" maddesi yer almakta ve "biomass estimation"çevr. Bir ortamda bulunan mikroorganizma sayısının ya da kütlesinin farklı yöntemler kullanılarak belirlenmesi" şeklinde tanımlanmaktadır (Ağ 2).

Toprak kalitesinin bir göstergesi olması bakımından ve ölçülebilme kolaylığı bakımından, çok yaygin olarak kullanılan bu terim, toprak mikrobiyolojisi çalışmalarında yaygın olarak kullanılmaktadır. Nitekim, ayrışma, bitkilerin besin maddesi alımı, toprak içindeki besin maddesi döngüleri, enzimatik aktiviteler ve toprak mikrobiyal kütlesinin aktivitesini ifade etmesi bakımından, çok yoğun bir kullanışa sahiptir (Culumber ve ark., 2019).

Mikrobiyal canlı kütle ifadesinde yer alan "canll" ifadesinin yer alıp almaması ile ilgili akla gelen soru şu şekilde olmaktadır: Mikroorganizmaların kütlesini ifade ediyorsa bu terim, ve mikroorganizmalar da canlı olduğuna göre, o halde, yine de bu kavramın ifadesinde "canlı" kelimesinin kullanılması gerekli midir? Yöntem itibariyle, cansiz olarak var olan ve organik madde kapsamında belirlenen kısmı, bu kav-ramın içinde yer almamaktadır. Yani, buradaki, mikroorganizmalar, esas itibariyle; iki aşamalı $\mathrm{CO}_{2}$ salımı üzerinden yapılan hesapla bulunmaktadır. Birinci aşamada, kloroform (KF) buharına (KFB) maruz birakilmadan kaydedilen $\mathrm{CO}_{2}$ salımı ve ikinci aşamada da kloroform buharına maruz birakılarak kaydedilen $\mathrm{CO}_{2}$ salımı arasındaki fark ile hesaplanmaktadır. İkinci aşamada, mevcut mikroorganizmaların (canlı) toplam parçalanan hücrelerinin, $\mathrm{KF}$ tarafindan öldürülen mikroorganizmaların sporları tarafindan ayrıștırılması sonucu açığa çıkan $\mathrm{CO}_{2}$ olarak tespit edildiği için (Carter ve ark., 1999) aslında, canlı ifadesinin kullanılmasına gerek vardır. Bu terimin kullanımı ile artık birliktelik içinde olan "mikrobiyal canlı kütle azotu", "mikrobiyal canlı kütle fosforu" gibi yan parametreler de belirlenmektedir.

Ölü örtü: Ölü örtü, orman ekosistemleri için çok önemli bir besin maddesi kompartmanı olup, besin maddesi döngüsünde, havuz olması bakımından çok büyük bir işleve sahiptir. Ölü örtü, Türkçe ormanc1lık bilim dilinde kabul görmüş ve yaygın olarak kullanilmakta olan bir terim olmakla birlikte, İngilizcede "forest floor" (Hanson ve ark., 1993; Putuhena ve Cordery, 1996), "forest litter" (Laskowski, 1995; McClaugherty, 1985), "forest humus layers" (Lafond, 1950; Kailsz ve Stone, 1980; Kögel, 1986) gibi terimlerin hepsinin ölü örtü olarak kullanıldığ1 ve anlam olarak aslında farklı anlamları olmakla birlikte, benzer bir kavramı ifade etmek için kullanıldıkları tespit edilmiştir. Türkçe olarak ölü örtü ifadesi; Irmak (1972) tarafindan; Toprak İlmi kitabında, "orman toprağınn yü̈z̈̈ӥ örten az veya çok ayrıșıs maddelerin bütüin̈" olarak tanımlanmış ve kullanılagelmiştir. Çepel (1982) ise ölü örtüyü: "Ormanda, toprağın üzerinde yaprak-çürüntü- ve humus tabakası olarak üst üste bulunan ve orman ağaçlarına ait organik döküntülerden oluşan (yaprak, kabuk, dal parçaları, tohum karpel vb.) organik madde tabakası" olarak tanımlamıştır.

Ölü örtünün kapsamına genellikle, yaprak, çürüntü ve humus tabakaları girmektedir. Bununla birlikte, yine de odunsu ölü örtü de yine ölü örtünün incelendiği çalışmalarda, ölü örtünün bir kısmı olarak ele alınabilmektedir (Tecimen ve ark., 2019). Bu terim, Türkçede net bir karş1llğa sahip olup, herhangi bir anlam bulanıklığı taşımamaktadır.

Odunsu ölü örtü: Ölü örtü kavramı içinde aslında çok farklı ölü örtü fraksiyonları yer almaktadır. Bunların en bilinenleri yaprak, çürüntü ve humus tabakalar1 olmakla birlikte, bir yandan da ölü örtüye eklendiği halde, araştırmalarda örnekleme yapılırken dahil edilmeyen veya farklı bir havuzu ifade ettiği için, ayrı olarak alınan odunsu kısımlar da ölü örtü olduğu halde, odunsu ölü örtü bileşenleri olarak ayrı bir örnekleme yapılır. Nitekim, ölü örtüdeki dağılımı, ayrışma ürünleri ve tuttuğu toplam karbon bakımından önemli olan ölü örtünün bu kısmı, ölü örtüden ayrı bir havuz olarak ele alınmaktadır (Tecimen ve ark., 2001; Tecimen ve ark., 2019). İngilizce literatürde "woody detritus" (Krankina ve ark., 1999; Harmon, 2001; Busing ve Fujimori, 2005), "terrestrial detritus" (Reiners, 1973), "detritus dynamics" (Flores-Verdigo, 1987), "aboveground detritus" (Fahey, 1983) şekil-lerinde kullanılmaktadır. Yabancı literatürdeki kullanı-lışları da yine Türkçede olduğu gibi ölü örtünün odunsu kısmına atıfta bulunmakta ve çalışmanın kapsamı ve amacına bağlı olarak, farklı işlevleri bakımından ele alınmaktadır.

\section{Organik madde/toprak organik maddesi:} $\mathrm{Bu}$ kavram için ayırım yapılması gereken en önemli husus, bir orman ekosisteminde toprak/ölü örtü sistemine ait toplam organik maddeden bahsedildiğinde, burada genellikle mineral toprağın içinde karışmış halde bulunan organik maddenin miktarı anlaşılmaktadır (Sparling ve ark., 2003). Zira, farklı tabakalardan oluşan ölü örtü kısımlarının \%80 ilâ 99'luk bir kısmı zaten 
organik maddeden oluşmaktadır. Ancak, toprak içinde yaşayan mikroorganizma toplumlarının beslenmeleri için büyük önem arz eden toprak içindeki organik maddenin miktarı, ayrışmaya yatkınlığı, ayrışma ürünleri ve ayrıştırıcılarının ortamda bulunması, toprak içindeki diğer kimyasal ayrışma ve madde dönüşümü olayları üzerinde de etkili olabilmektedir. Gerçekten de iklim, ağaç türü ve ormanın genel yapısı ölü örtünün ayrışması ile toprağa karışacak organik maddenin miktarı üzerinde en önemli faktörlerdir (Tecimen ve Sevgi 2008; Sevgi ve Tecimen 2008; Sevgi ve Tecimen 2009; Sevgi ve ark. 2011). Bununla birlikte, genel olarak, organik maddenin, bitki ve hayvan kökenli, protein, şeker, nişasta, selüloz, lignin vb. gibi maddeler içeren ve tüm organik maddelerin karbon içermesi özellikleri bulunan madde olarak tanımlandığ1 görülmektedir (Çepel, 1996). Gülçur (1952) tarafindan yapılan çalışmada, "toprak organik maddesi" tabiri, parantez içinde "toprak humusu" ile açklanarak kullanılmıştır. Bununla birlikte, toprağın karbon içeriğinin, Shollenberger Islak yakma yöntemi ile tayin edildiği belirtilmiştir.

Toprak çözeltisi: Toprak çözeltisi, besin maddelerinin değiştirilme - taşınma - uzaklaşma veya bir ortamdan diğerine geçme ortamı ve havuzudur (Yanai ve ark., 1998). Toprakta tutulan besin madde-lerinin çoğu, toprağın katı fazında tutulmakla birlikte, iklim, anakaya ve bitki örtüsüne bağlı olarak, toprak çözeltisinin önemli miktarda besin maddesini bulun-durduğu bilinmektedir. Her ne kadar, toprak suyu olarak da kullanilmakta olan bir kavram bulunsa da "çözelti” içinde çözünmüş maddelerin bulunduğu sıvı olarak tanımlandığı için besin maddesi bulundurduğu anlamını daha fazla taşımaktadır. Zira toprak suyu diye anılan kavramdan, toprak içinde hareket halinde bulunan ve içinde çözünmüş madde bulundurmaktan ziyade, bitkilerin yaşamsal ihtiyacını karşılayan, toprağın belirli bir nem düzeyinde olmasına neden olan ve toprak içinde alınmadığ takdirde yer altı su sistemlerine eklenen ve mineral bakımından zenginliğine vurgu yapilmayan su varlığından bahsedildiği düşünül-mektedir. Bununla birlikte, toprak çözeltisi denildiği zaman da, toprakta bulunan; toprağın, anakayanın ve toprak üzerindeki bitki örtüsüne bağlı olarak içinde muhtelif düzeylerde besin elementlerini bulunduran ve toprakta besin maddesi havuzu niteliği taşıyan bir toprak bileşeninden bahsedildiği çok açık olarak anlaşılamamaktadır. Daha ziyade, toprağın su ile karıştırılarak ve belirli bir amaç için kullanılmak üzere yapay olarak hazırlanmış bir karışımı anlattığı düşünülmekte ve belirsizlik taşımaktadır. Nitekim Çepel (1996)'da toprak suyu maddesi "toprak taneciklerinin arasinda ve yüzeyinde tutulan sü" olarak tanımlanmıştır. TÜBA Bilim Terimleri Sözlüğü’nde tarım bilimleri açısından yapılan tanımlamada; toprak çözeltisi maddesi; (müh.) (Alm. Bodenlösung, f; Fr. solution du sol, f; İng. soil solution)tar. Toprak sıvı fazı, içerisinde çözünmüş çeşitli iyon, molekül ve diğer bileşikleri kapsayan sıvı ortam olarak tanımlanmıştır. Toprak suyunun aynı zamanda, toprak çözeltisi anlamında kullanılması seçeneği veya toprak çözeltisinin toprak suyundan farklı olarak, içinde besin maddelerini bulunduran ortam olarak kullanılmas1 seçeneğinden ayrı olarak, başka bir terimin bu anlamı ifade etmesi için önerilmesi seçeneği de açık olmalıdır. Burada yapıla-bilecek öneri "toprak sıvısı" terimi olup, toprağın özelliklerini ve besin maddesi konsantrasyonlarını içeren ve toprağın sıvı fazını ifade eden bir kavram olarak kullanılması mümkündür. Toprak çözeltisi anlamında, yabancı literatürde ilk defa 1905 yilinda Cameron ve Bell tarafindan yapilan "Mineral constituents of the soil solution." başlıklı yayında kullanılmışır. Eruz (1979) tarafindan yapılan toprak tuzluluğunun incelendiği çalışmada, "toprak çözeltisi” terimi, topraktaki tuzların ve diğer besin elementlerinin tutulduğu bir toprak suyu + elementleri karışımı olarak kullanılmıştır. Dolayısıyla, bu terimin, bu hâliyle kullanılması iyi bir seçenek olarak durmaktadır.

Toprağın mineral elementleri: Toprağın kat1 fazında, değiştirilebilir, zor değiştirilebilir, ayrışmamış, organik ve inorganik kökenli muhtelif karışımlarda bulunan bütün besin maddelerini kapsayan ve besin maddesi olarak bitkiler tarafindan alınmayan elementleri de kapsayan havuzu işaret etmektedir. Toprak mineralleri, toprak elementleri, makro/mikro besin elementleri, bitki besin maddeleri veya bitki besin elementleri gibi farklı kısımları ifade eden bu terimlerin hepsi, toplamda, toprağın besin maddesi havuzunun tamamını veya bir kısmını ifade etmekte ve zaman zaman yanlış kullanışları ile, toprağın toplam element havuzu anlatmak istenirken, sadece bir kısmından bahsedilmiş olunmaktadır. Bu itibarla, yerkürenin yapi-sında bulunan iz elementler denilen ve toprakta çok az miktarlarda bulunan elementler ile, makro elementler denilen ve topraklarda genel olarak bol miktarda bulunan elementler dişında, radyoaktif elementler de dahil olmak üzere pek çok element bulunmaktadır (Menzel, 1965). Anakaya denilen ve toprağın oluşu-munda, minerallerin ana kaynağını oluşturan kayalar, topraktaki minerallerin içeriğinin ne olacă̆ı hakkında en doğru fikri vermektedir. Tyler (2004) tarafindan yapılan bir çalışmada, toprakta itriyum, lantan, praseodim, neodim gibi yerkürenin yapısında çok düşük miktarlarda bulunan elementlerin dahi toprakta bulunduğunu, llıman iklim topraklarında ayrışma ve yıkanma olaylarından dolayı, $A$ ve $E$ horizonlarından ziyade, daha alt horizonlarda bulunduğu bildirilmiştir. Tyler ve Olsson (2001), 60 elementin toprakta bulunuşunun, toprağın asitliğine bağl1 olarak nasıl değiştiğini incelemiş ve ele alınan elementlerin içinde çok ender bulunan elementlerin dahi bulunduğu görülmüştür. Robinson ve ark. (1915) tarafindan, topraktaki elementlerin varlığ ile ilgili çalışmalara rastlanmıştır. Bu kitapta, topraklarda bulunan nadir 
elementlerin, bitkilerde de bulunuşları arasında bir korelasyonun varlığına dair ipuçları aran-mıştır. Toprağın elementleri, toprakta yetişen bitkilerin beslenme kalitesi, gücü ve niteliği hakkında belirleyici olması bakımından özel bir önem arz etmekte ve ülkemizde ve dünyada bu konu uzun ylllardan beri bilimsel alanda konu edilmiştir. Sevim (1951,1952) Türkiye orman topraklarının elementleri hakkında kap-samlı çalışmalar yapmıştır. Bu çalışmalarda, topraktaki önemli elementlerden, "toprağın baz miktarı" olarak bahsedilmiştir. Türkçe yayınlarda, en s1klıkla "bitki besin maddesi" kavramının kullanıldığına rastlanmıştır (Gülçur, 1961; Özyazıcı ve ark., 2015). Irmak ve Çepel tarafindan yapilan yayınlarda da yine "besin maddesi" olarak kullanıldığı, konu başlığına bitki kelimesinin eklenmeden kullanıldığ1 görülmüsstür (Irmak, 1963; Çepel ve Irmak, 1968).

\section{Değerlendirme ve Sonuç}

Yapılan çalş̧ma sonucunda, toprak havuzu terimlerinin Türkçe literatürde kullanilma durumları hakkında genel bir fikir elde edilmiş olup, özellikle son yıllarda, Türkçe yerine İngilizce yayın yapılmasının, ve topraktaki besin maddesi havuzlarna dair terimlerin doğrudan İngilizce olarak kullanılmasının sonucu olarak, bu terimlerin bazılarının Türkçeye uygunluğu konusu üzerinde durulmadan kullanılmakta olduğu anlaşılmıştır. Bununla birlikte, uzun zamandan beri kullanilmakta olan ve üzerinde hemfikir olunan terimlerin, olduğu hâlleriyle bilimsel yazılarda kullanılan dile sağlam bir şekilde yerleştiği görülmektedir. Üzerinde daha sıklıkla çalışılan konularda, hem Türkçe hem de yabancı dilde kullanılan ilgili havuz terimlerinin ne olacağ hakkında daha kararlı bir yaklaşımın bulunduğu tespit edilmiştir.

Bu çalışmada yer verilen besin maddesi havuzu terimlerinin kullanımlarındaki süreklilik incelendiğinde;

Ölü örtü ve organik maddeyi konu alan çalışmaların, 1960-70'li yıllardaki tanımlamaların esas alınarak kullanılmaya devam edildiği düşünülürse, yaklaşık 50 yıllık bir süredir aynı şekilde kullanılmakta olduğu;

Bitkisel canlı kütle, mikrobiyal canlı kütle ve odunsu ölü örtü terimlerinin; gerek üzerinde fazla çalışma yapılmamış olmasından ve gerekse de bu terimler ile ilgili yapılan çalışmaların daha ziyade son yıllarda yapilmış olmasindan kaynaklanan sebeplerle bu terimlerin Türkçe karşıllklarının kullanımında bir süreklilik ve tutarllık olmadığ1;

Odunsu ölü örtü, toprağın besin elementleri ve toprak çözeltisi terimleri üzerinde gerek fazla çalışma yapılmamıs olmasından ve gerekse de bu terimler ile ilgili yapılan çalışmaların İngilizce olarak yapilmakta olmasından kaynaklanan sebeplerle bu terimlerin Türkçe karşılıklarının kullanımında bir süreklilik ve tutarlılık olmadığ tespit edilmiştir.

$\mathrm{Bu}$ itibarla, bu çalışmadan, yayınların Türkçe olarak yapılması ve yapılan çalışmaların Türkçe yayın yapılan mecralarda paylaşılarak uzun yıllar devam edilmesi hâlinde, terimlerin Türkçe kullanımlarında tutarlılık ve sürekliliğin sağlanacağı anlaşılmaktadır.

\section{Kaynaklar}

\section{Ağ1., 2020. TÜBA Terimler Sözlüğü.}

http://www.tubaterim.gov.tr/ATS/index.php/w_ anasayfa/search/?q=biyok $\% \mathrm{C} 3 \%$ BCtle+\&arama options $=1 \&$ szl $=20 \% 2 \mathrm{C} 23 \% 2 \mathrm{C} 32 \& \operatorname{lng}=1 \% 2 \mathrm{C} 2 \%$ 2C3\&relational_search $=\#$ (Ziyaret saati ve tarihi: 11:51 12.03.2020).

A ğ 2., 2020. TÜBA Terimler Sözlüğü. http://www.tubaterim.gov.tr/ATS/index.php/w_ anasayfa $/$ search $/$ ?q $=$ mikrobiyal\&arama_options $=$ $4 \&$ szl $=20 \% 2 \mathrm{C} 23 \% 2 \mathrm{C} 32 \& \operatorname{lng}=1 \% 2 \mathrm{C} 2 \% 2 \mathrm{C} 3 \&$ rela tional_search=\# (Ziyaret saati ve tarihi: 11:49 12.03.2020).

Anderson, D. W., 1988. The effect of parent material and soil development on nutrient cycling in temperate ecosystems. Biogeochemistry, 5(1): 71-97.

Baskerville, G. L., 1972. Use of logarithmic regression in the estimation of plant biomass. Canadian Journal of Forest Research, 2(1): 49-53.

Bormann, F. H., Likens, G. E., 1967. Nutrient cycling. Science, 155 (3761): 424-429.

Brady, N. C., Weil, R. R., Weil, R. R., 2008. The nature and properties of soils (Vol. 13, pp. 662-710). Upper Saddle River, NJ: Prentice Hall.

Busing, R. T., Fujimori, T., 2005. Biomass, production and woody detritus in an old coast redwood (Sequoia sempervirens) forest. Plant Ecology, 177(2): 177-188.

Cameron, F. K., Bell, J. M., 1905. Mineral constituents of the soil solution. United States, Bureau of soils.

Carter, M. R., Gregorich, E. G., Angers, D. A., Beare, M. H., Sparling, G. P., Wardle, D. A., Voroney, R. P., 1999. Interpretation of microbial biomass measurements for soil quality assessment in humid temperate regions. Canadian Journal of Soil Science, 79(4): 507-520. 
Çepel, N., 1982. Ekoloji Terimleri Sözlüğü (Almancaİngilizce-Türkçe). İstanbul Üni. Yayın Nu: 3048, Or. Fak. Yay. Nu: 324, 356 sayfa, Taş Matbaası.

Çepel, N., 1988. Toprak İmi. İstanbul Üniversitesi Orman Fakültesi Yayını Nu: 3416.

Çepel, N., 1996. Çevre koruma ve ekoloji terimleri sözlüğ̈̈: Türkece-Almanca-İngilizce. TEMA Vakfi.

Çepel, N., Irmak, A., 1968. Belgrad ormanı'nda seçilen birer kayın, meşe ve karaçam meşceresinde y1llik yaprak dökümü miktarı ve bu yolla toprağa verilen besin maddelerinin tesbiti üzerine araştırmalar. Istanbul Üniversitesi Orman Fakültesi Dergisi, 18 (2):18.

Culumber, C. M., Reeve, J. R., Black, B. L., Ransom, C. V., Alston, D. G., 2019. Organic orchard floor management impact on soil quality indicators: nutrient fluxes, microbial biomass and activity. Nutrient Cycling in Agroecosystems, 115(1), 101-115.

Demura, T., Ye, Z. H., 2010. Regulation of plant biomass production. Current opinion in plant biology, 13(3): 298-303.

Eruz, E., 1979. Toprak tuzluluğu ve bitkiler üzerindeki genel etkileri. Istanbul Üniversitesi Orman Fakültesi Dergisi, 29 (2):112-120.

Fahey, T. J., 1983. Nutrient dynamics of aboveground detritus in lodgepole pine (Pinus contorta ssp. latifolia) ecosystems, southeastern Wyoming. Ecological Monographs, 53(1): 51-72.

Flores-Verdugo, F. J., Day Jr, J. W., Briseño-Dueñas, R., 1987. Structure, litter fall, decomposition, and detritus dynamics of mangroves in a Mexican coastal lagoon with an ephemeral inlet. Marine Ecology Progress Series, 35(27): 83-90.

Fransen, B., de Kroon, H., De Kovel, C. G. F., van den Bosch, F., 1999. Disentangling the effects of root foraging and inherent growth rate on plant biomass accumulation in heterogeneous environments: a modelling study. Annals of Botany, 84(3): 305-311.

Gülçur, F., 1952. Kuzey Anadolu ormanlarının bazı meşcerelerinde toprak humusu üzerine araştırmalar. Istanbul Üniversitesi Orman Fakültesi Dergisi, 2(1): 153-184.

Gülçur, F., 1961. Toprağın reaksiyonu ve toprak reaksiyonunun bitki besin maddelerinden olan istifadeye tesiri. İstanbul Üniversitesi Orman Fakültesi Dergisi, 11(2):51-59.

Güner, D., Özkan, K., 2019. Türkiye'deki karaçam ağaçlandırma alanlarında besin stoklarının belirlenmesi. Ormancullk Araştırma Dergisi, 6(2): 192207.

Hanson, P. J., Wullschleger, S. D., Bohlman, S. A., Todd, D. E., 1993. Seasonal and topographic patterns of forest floor $\mathrm{CO}_{2}$ efflux from an upland oak forest. Tree physiology, 13(1): 1-15.

Harmon, M. E., 2001. Moving towards a new paradigm for woody detritus management. Ecological Bulletins, 49:269-278.

Irmak, A., 1963. Topraklı fidanlarla kaydedilen toprak ve besin maddesi miktar1. Istanbul Üniversitesi Orman Fakültesi Dergisi. 13:36-39.

Irmak, A., 1970. Orman Ekolojisi. İstanbul Üniversitesi Yayın No: 1650, Orman Fak. Yayın No: 149, Taş Matbaas1, 367 sayfa.

Irmak, A., 1972. Toprak İmi. İstanbul Üniversitesi Yayın No: 1268, Orman Fak. Yayın No: 121, Taș Matbaas1 300 sayfa.

Jandl, R., Rodeghiero, M., Martinez, C., Cotrufo, M. F., Bampa, F., van Wesemael, B., Lorenz, K., 2014. Current status, uncertainty and future needs in soil organic carbon monitoring. Science of the Total Environment, 468: 376-383.

Kalisz, P. J., Stone, E. L., 1980. Cation exchange capacity of acid forest humus layers. Soil Science Society of America Journal, 44(2): 407-413.

Karaöz, Ö., 1988. Belgrad ormanında bazı iğne yapraklı ve geniş yapraklı orman ekosistemlerinin önemli edafik özellikleri ile bitkisel kütle karakteristikleri bakımından karşılaştırılması. İstanbul Üniversitesi Orman Fakültesi Dergisi, 38(1): 156-190.

Kögel, I., 1986. Estimation and decomposition pattern of the lignin component in forest humus layers. Soil Biology and Biochemistry, 18(6): 589-594.

Krankina, O. N., Harmon, M. E., Griazkin, A. V., 1999. Nutrient stores and dynamics of woody detritus in a boreal forest: modeling potential implications at the stand level. Canadian Journal of Forest Research, 29(1): 20-32. 
Kriss, A. Y., Rukina, Y. A., Tikhanenko, A. S., 1950. The microbial biomass on the sea floor in the hydrogensulphide region of the Black Sea. In Dokl. Akad. Nauk SSSR (Vol. 89, No. 5).

Laclau, J. P., Ranger, J., de Moraes Gonçalves, J. L., Maquère, V., Krusche, A. V., M'Bou, A. T., Deleporte, P., 2010. Biogeochemical cycles of nutrients in tropical Eucalyptus plantations: main features shown by intensive monitoring in Congo and Brazil. Forest ecology and management, 259(9): 1771-1785.

Lafond, A., 1950. Oxidation-Reduction Potential as a Characteristic of Forest Humus Types 1. Soil Science Society of America Journal, 14(C): 337-340.

Laskowski, R., Niklinska, M., Maryanski, M., 1995: The dynamics of chemical elements in forest litter. Ecology, 76(5): 1393-1406.

McCarthy, M. C., Enquist, B. J., 2007: Consistency between an allometric approach and optimal partitioning theory in global patterns of plant biomass allocation. Functional Ecology, 21(4): 713720 .

McClaugherty, C. A., Pastor, J., Aber, J. D., Melillo, J. M., 1985. Forest litter decomposition in relation to soil nitrogen dynamics and litter quality. Ecology, 66(1): 266-275.

Menzel, R. G., 1965. Soil-plant relationships of radioactive elements. Health Physics, 11(12): 13251332.

Moscatelli, M. C., Fonck, M., De Angelis, P., Larbi, H., Macuz, A., Rambelli, A., Grego, S., 2001. Mediterranean natural forest living at elevated carbon dioxide: soil biological properties and plant biomass growth. Soil use and management, 17(3): 195202.

O'Neill, R. V., Ausmus, B. S., Jackson, D. R., Van Hook, R. I., Van Voris, P., Washburne, C., Watson, A. P., 1977. Monitoring terrestrial ecosystems by analysis of nutrient export. Water, Air, and Soil Pollution, 8(3), 271-277.

Özyazıc1, M. A., Dengiz, O., Aydoğan, M., Bayraklı, B., Kesim, E., Urla, Ö., Ünal, E., 2015. Orta ve Doğu Karadeniz Bölgesi tarım topraklarının bazı makro ve mikro bitki besin maddesi konsantrasyonları ve ters mesafe ağırlık yöntemi (IDW) ile haritalanması. Artvin Coruh Üniversitesi Orman Fakültesi Dergisi, 16(2): 187-202.
Putuhena, W. M., Cordery, I., 1996. Estimation of interception capacity of the forest floor. Journal of Hydrology, 180(1-4): 283-299.

Rao, R. P., 1913. Biofuels-Feasibility of Using Algae Biomass in ABE Process Interactive Qualifying Project Report completed in partial fulfillment of the Bachelor of Science degree at (Doctoral dissertation, Worcester Polytechnic Institute).

Reiners, W. A., 1973. Terrestrial detritus and the carbon cycle. Atmosphere, 700: 1-76.

Robinson, W. O., Steinkoenig, L. A., Miller, C. F., 1917. The relation of some of the rarer elements in soils and plant. No: 600. US Department of Agriculture.

Schulz, S., Brankatschk, R., Dümig, A., Kögel-Knabner, I., Schloter, M., Zeyer, J., 2013. The role of microorganisms at different stages of ecosystem development for soil formation. Biogeosciences, 10(6): 3983-3996.

Sevgi, O., Tecimen, H. B., 2008. Changes in Austrian Pine forest floor properties in relation with altitude in mountainous areas. Journal of Forest Science, 54(7): 306-313.

Sevgi, O., Tecimen, H. B., 2009. Physical, chemical and pedogenetical properties of soil in relation with altitude at Kazdagi upland black pine forest. $J$. Environ. Biol, 30(3): 349-354.

Sevgi, O., Tecimen, H., Çobanoğlu, G., Sevgi, E., Yılmaz, O., 2011. Alaçam Dağları Karaçam Ormanlarının Liken Ölü Örtü pH'sının İrdelenmesi. İstanbul Üniversitesi Orman Fakültesi Dergisi, 61(2): 45-52.

Sevim, M., 1951. Alaçam (Dursunbey) ormanında ekolojik ve pedolojik araştırmalar (Untersuchungen über die Standorts-und Bodenverhaltnisse im Alaçam Waldgebiet (Dursunbey). Journal of the Faculty of Forestry, Istanbul University. 1(1): 115-142.

Sevim, M., 1952. Lübnan sedirinin (Cedrus libani Barr.) Türkiye'deki tabi yayılışı ve ekolojik şartları (Die Naturliche verbreitung und standortsbedingungen der Libanonzeder (Cedrus libani Barr.) in der Turkei. İstanbul Üniversitesi Orman Fakültesi Dergisi, 2(2): 1946.

Sharma, J. C., Sharma, Y., 2004. Nutrient cycling in forest ecosystems-A review. Agricultural Reviens, 25(3): 157-172. 
Sparling, G., Parfitt, R. L., Hewitt, A. E., Schipper, L. A. (2003). Three approaches to define desired soil organic matter contents. Journal of Environmental Quality, 32(3): 760-766.

Svoboda, M., Matějka, K., Kopáček, J. (2006). Biomass and element pools of selected spruce trees in the catchments of Plešné and Čertovo Lakes in the Šumava Mts. J. For. Sci, 52(10): 482-495.

Tecimen, H. B., Sevgi, O., Yllmaz, O. Y., Carus, S., Kavgac1, A., Akburak, S., 2019. Estimation of forest litter fractions by regression analysis in different aged stands of Pinus nigra. Bosque, 40(1): 41-48.

Tecimen, H., Sevgi, O. (2008). Orman topraklarında mikroorganizmalar tarafindan gerçekleştirilen azot dönüşümleri. Türkiye Ormancllık Dergisi, 9(1), 179189.

Tecimen, H.B., Sevgi, O., Makineci, E., 2001, Investigations on Physical and Chemical Properties of Forest Floor in Turkey, Fifth International Conference On Wood Science, Technology And Forestry, September 2001, Ljubljana, Slovenia.

Tolunay, D., 2012. Bolu-Aladağ'daki genç sarıçam meşcereleri için oluşturulan bitkisel kütle denklemleri ve katsayıları. Istanbul Üniversitesi Orman Fakültesi Dergisi, 62(2): 97-111.

Tyler, G., 2004. Rare earth elements in soil and plant systems-A review. Plant and soil, 267(1-2): 191-206.

Tyler, G., Olsson, T., 2001. Concentrations of 60 elements in the soil solution as related to the soil acidity. European Journal of Soil Science, 52(1), 151165.

van der Heijden, G., Legout, A., Mareschal, L., Ranger, J., Dambrine, E., 2017. Filling the gap in Ca inputoutput budgets in base-poor forest ecosystems: The contribution of non-crystalline phases evidenced by stable isotopic dilution. Geochimica et Cosmochimica Acta, 209: 135-148.

Vance, E. D., Brookes, P. C., Jenkinson, D. S., 1987. An extraction method for measuring soil microbial biomass C. Soil biology and Biochemistry, 19(6): 703707.

Yanai, J., Robinson, D., Young, I. M., Kyuma, K., Kosaki, T., 1998. Effects of the chemical form of inorganic nitrogen fertilizers on the dynamics of the soil solution composition and on nutrient uptake by wheat. Plant and Soil, 202(2): 263-270. 